\title{
Bdellovibrio sp: An Important Bacterial Predator in Lake Geneva?
}

\author{
Ezzedine JA, Pavard G, Gardillon M and Jacquet $\mathrm{S}^{*}$
}

Universite Savoie Mont-Blanc, INRAE, France

*Corresponding author: Jacquet S, INRAE-Universite Savoie Mont-Blanc, UMR CARRTEL, Thonon-Les-Bains, France, Tel: 33450267812; Email: stephan.jacquet@inrae.fr

\section{Research Article \\ Volume 5 Issue 1}

Received Date: December 17, 2019

Published Date: January 17, 2020

DOI: $10.23880 /$ oajmb-16000157

\section{Abstract}

We describe a new Bdellovibrio and like organism (BALO) isolated from Lake Geneva. The bacterial predator is a new member of the genus Bdellovibrio (Bdellovibrionaceae), enable to reproduce mainly on Pseudomonas spp preys. To achieve this goal, we used a variety of preys so that we also tested in parallel the host range of other well-known and characterized strains of Bdellovibrio such as B. exovorus JSS. Among original results, we observed that these BALOs could also grow on a fish pathogen, i.e. Aeromonas salmonicida salmonicida which is responsible for salmonid furunculosis, providing thus a new potential therapeutic agent against this bacterial infection in freshwater fish farming. This work sheds light on a functional group of bacteria still largely unknown.

Keywords: Bdellovibrio sp; Bacterial Predator; Preys; Isolation; Lake Geneva

Abbreviations: BALO: Bdellovibrio and Like Organisms; SDS: Sodium Dodecyl Sulfate; BSA: Bovine Serum Albumin.

\section{Introduction}

Aquatic microorganisms, i.e. viruses, bacteria, Achaea and unicellular eukaryotes, are abundant, diversified, and play major roles in the functioning of ecosystems [1]. Microbiologists have long relied on the principle that microorganisms existed only if they were cultivable [2]. However, it is well known now that only a very small fraction $(<1 \%)$ of these microorganisms are likely to grow on laboratory conditions [3]. This is not really surprising when one knows that unicellular organisms may live, grow and reproduce in a variety of environments where a multitude of parameters may intervene both in terms of quantity and quality (e.g. light, temperature, nutrients, $\mathrm{pH}$, etc...) not to mention the biotic interactions (predation, parasitism, etc...). In fact, the huge diversity of microorganisms has been highlighted mainly by the advent and use of tools derived from molecular biology: PCR, cloning-sequencing, meta genomics, high-throughput sequencing. It remains, however, that the different interactions between these microorganisms and their environment, as well as their functional roles, often have to be explored, and, for this purpose, isolation based methods still represent a scientific interest. This is typically the case for many bacteria (comprising a large microbial community, consisting of species considered pathogenic to humans, animals and plants, as well as beneficial species that interact with other organisms, not to mention their various ecological roles), for instance the Bdellovibrio and like organisms (BALOs).

BALOs are composed of Gram-negative bacteria, and they are obligate predatory bacteria of other Gram-negative bacteria. Two life cycles exist among BALOs, the endobiotic cycle where the prey is shaped as a bdelloplast and consumed from the inside, vs. a periplasmic cycle with an external consumption of the prey [4]. BALOs are composed of 5 families: the Bdellovibrionaceae, the Peredibacteraceae, the Bacteriovoracaceae, the Halobacteriovoraceae and the Pseudobacteriovoracaceae, all belonging to the Oligoflexia class [5]. A little bit apart, one genus, the Micavibrio, belongs to the Alpha-proteo bacteria class. In general, BALOs are 


\section{Open Access Journal of Microbiology \& Biotechnology}

morphologically similar and look like a comma shape form with a flagellum, and measure between 0.2 to $0.5 \mu \mathrm{m}$ in width and 0.5 to $2.5 \mu \mathrm{m}$ in length [6]. BALOs have different predation strategies; some are generalists with a broad spectrum of preys, while others are specialized on a few preys [7]. The high diversity and ubiquitous nature of BALOs has implications on the structure and dynamics of microbial communities [8]. Indeed, it is assumed that BALOs may act as an ecological balancer". In other words, they could regulate bacterial biomass and diversity like bacteriophages and small protists do $[9,10]$. BALOs in freshwater ecosystems have been poorly studied [11-16], and this is particularly true for lakes.

Recently, we proved the existence of BALOs in large and deep peri-alpine lakes [17]. Using a cloning-sequencing (Sanger) approach and quantitative PCR, we found that, while the Peredibacteraceae family was represented mainly by a single species (Peredibacter starrii), it could represent up to $7 \%$ of the total bacterial cell abundances. Comparatively, the abundances of two other families (i.e. the Bdellovibrionaceae and Bacteriovaracaceae) were significantly lower. In addition, the distribution in the water column was very different between the three groups suggesting various life strategies/ niches: Peredibacteraceae dominated near the surface while Bdellovibrionaceae and Bacteriovaracaceae were more abundant at greater depth. On the basis of these results and to go deeper in the knowledge about the possible importance of BALOs in the microbial functioning of lakes, we tried to isolate and characterize new BALOs as well as their potential preys from Lake Geneva. Our aims were thus multiple and consisted in: (I) isolating, growing and identifying potential BALOs and preys from different origins, and (ii) defining host-range for the predators.

\section{Material and Methods}

Prey isolation, selection, and culturing from different origins Preys used in this study were from four different origins. Firstly, five standard reference (Gram-) bacteria were ordered from the Centre International de Ressources Microbiennes (CIRM) (https://www6.inra.fr/cirm_eng/)": Citrobacter freundii ATCC 8090, Escherichia coli ATCC 10536, Hafnia alvei ATCC 13337, Pseudomonas fluorescens ATCC 13525 and P. putida ATCC 12633. These bacteria were cultured on liquid LB medium (Trypton $10 \mathrm{~g}$, Yeast extract $5 \mathrm{~g}, \mathrm{NaCl} 10 \mathrm{~g}$ ) and incubated at $25^{\circ} \mathrm{C}$ under low shaking at $200 \mathrm{rpm}$. The second source of potential preys was obtained from a mixed sample of water issued from Lakes Geneva, Bourget and Annecy and of the Dranse River (ALBD). From each source, $100 \mathrm{ml}$ of water was collected and mixed. The third source of bacteria was obtained from 25 non-axenic cultures of freshwater microalgae, all isolated from Lake Geneva and stored in the Thonon Culture Collection (TCC)" (https://www6.inra.fr/carrtel-collection_eng/) hold in our laboratory. Briefly, $3 \mathrm{ml}$ of culture were collected and mixed together. For the two latter sources, samples were filtered through microfiber filters (Whatman, GF/F, $47 \mathrm{~mm}$ ), and polycarbonate filters of 5 and $2 \mu \mathrm{m}$ (ipPoRE). Then filtrates were distributed in Falcon tube of $50 \mathrm{ml}$ and centrifuged at $12,000 \mathrm{~g}$ for $20 \mathrm{~min}$. The pellet was dissolved with $3 \mathrm{ml}$ of PBS $1 \mathrm{X}\left(\mathrm{NaCl} 8 \mathrm{~g}, \mathrm{KCl} 0.2 \mathrm{~g}, \mathrm{Na}_{2} \mathrm{HPO}_{4} 1.44 \mathrm{~g}, \mathrm{KH}_{2} \mathrm{PO}_{4} 0.24 \mathrm{~g}\right)$. Finally, $1 \mathrm{ml}$ were distributed into 3 flasks containing $30 \mathrm{ml}$ of $\mathrm{LB}$ medium and incubated for $48 \mathrm{~h}$ at $25^{\circ} \mathrm{C}$ under low shaking at $200 \mathrm{rpm}$. After incubation, the cell concentration was estimated by flow cytometry (not shown). The cultures were then diluted 10 fold up to $10^{-7}$ in PBS $1 \mathrm{X}$, and $100 \mu \mathrm{l}$ of each dilution was spread on LB agar plate $(15 \mathrm{~g} / \mathrm{l})$ and incubated for $24 \mathrm{~h}$ at $25^{\circ} \mathrm{C}$. Isolated colonies so obtained of different shapes and colors were selected and cultured in liquid LB medium for $24 \mathrm{~h}$ at $25^{\circ} \mathrm{C}$ under low shaking at $200 \mathrm{rpm}$. Then, the culture was centrifuged at $5,000 \mathrm{~g}$ at $4^{\circ} \mathrm{C}$ for $10 \mathrm{~min}$ and the supernatant was discarded. The pellet was dissolved in a few milliliter of HM buffer (HEPES $6 \mathrm{~g}$, 15g agar, $6 \mathrm{ml} \mathrm{\textrm {CaCl } _ { 2 }}$ $\left.(0.5 \mathrm{M}), 3.33 \mathrm{ml} \mathrm{MgCl}_{2}(0.6 \mathrm{M})\right)$ to obtain a concentration of about $10^{10}$ cells per $\mathrm{ml}$ in order to be used for BALOs enrichment. The cell concentration was obtained by reading optical density (OD) at $600 \mathrm{~nm}$. Each culture was colored using a Gram stain kit (Sigma-Aldrich) according to the manufacturer's instructions. Finally, the species Aeromonas salmonicida salmonicida SA28 recently characterized and isolated from farmed Arctic chars (Salvelinus alpinus) infected with furunculosis (Jacquet unpublished) was also tested as a potential prey. Specific Fur medium (Tryptone 10 $\mathrm{g}$, yeast extract $5 \mathrm{~g}$, NaCl $2.5 \mathrm{~g}$, Tyrosine $1.0 \mathrm{~g}$ ) was used to grow the species.

\section{Sampling and Enrichment of BALOS}

A few litters of water mixed with biofilms on rocks and sediment were sampled on April 2, 2019 in a coastal area of Lake Geneva next to our research institute. Immediately, the sample was filtered as above and $100 \mathrm{ml}$ was used for the enrichment step (see below), with $5 \mathrm{ml}$ of each concentrated prey sources (CIRM, ALBD, TCC). A negative control was prepared with filtered sterile lake water to which preys were added. All flasks were placed in a hot chamber at $25^{\circ} \mathrm{C}$ and gently shacked at $200 \mathrm{rpm}$. Each flask was examined daily for a decrease in turbidity, a marker of bacterial prey concentration decrease. Also, a drop of each sample was observed under phase-contrast microscopy for fast moving cells, a marker of BALO presence.

\section{Predator Isolation and Growth on Double-Layered Agar Plates}

We applied the protocol proposed by Jurkevitch [18] to isolate BALOs. $50 \mathrm{ml}$ of each enriched culture were 


\section{Open Access Journal of Microbiology \& Biotechnology}

centrifuged at $500 \mathrm{~g}$ for 5 minutes at $4^{\circ} \mathrm{C}$. The supernatant was then centrifuged at $27,000 \mathrm{~g}$ for 20 minutes at $4^{\circ} \mathrm{C}$. The pellet was taken up with $3 \mathrm{~mL}$ of HM buffer and filtered through $1.2 \mu \mathrm{m}$. This filtrate containing the possible predators was used to achieve a dilution range of 10 to $10^{-4}$ in a final volume of $5 \mathrm{~mL}$ of HM buffer. $100 \mu \mathrm{L}$ of each dilution were added to $4 \mathrm{~mL}$ of molten $\mathrm{HM}$ top agar $(0.5 \%)$, supplemented with $300 \mu \mathrm{L}$ of prey at $10^{10} \mathrm{cells} / \mathrm{ml}$. For each dilution of predator, one type of prey was added. After mixing it rapidly, the HM top was poured on a Petri dish containing $20 \mathrm{~mL}$ of solid HM (15\%). Once the top HM was solidified, the dishes were sealed with Parafilm and incubated at $25^{\circ} \mathrm{C}$. After 5 to 8 days of incubation, the presence of transparent halos of a few millimeters (resembling lysis plaques) testified of the consumption of the tested prey. These predation plaques were then removed by means of a $1 \mathrm{ml}$ pipettor tips having been previously cut by a sterile scalpel. The agar piece was then resuspended in $500 \mu \mathrm{L}$ of HM buffer. The presence of BALOs in the suspension was confirmed by microscopy observation. When fast moving cells were detected, the suspension was filtered through $0.45 \mu \mathrm{m}$ filter. This isolation step was repeated three times to obtain a "purified" strain of BALO. Finally, half of the suspension was stored in glycerol $(20 \%)$ at $-80^{\circ} \mathrm{C}$ and half was processed for DNA extraction.

\section{DNA Extraction}

DNA extraction was performed on both preys and predators. For BALOs, liquid medium were filtered with 0.45 $\mu \mathrm{m}$ pore size filters in order to remove larger microorganisms such as prey cells. All samples were then centrifuged for 3 $\min$ at $6,000 \mathrm{~g}$ and at $4^{\circ} \mathrm{C}$. The supernatant was discarded and the pellet was used for DNA extraction. We used a homemade protocol combined with GenEluteTM-LPA (Sigma-Aldrich) solution. Briefly, the protocol began with a lysis step by adding $300 \mu \mathrm{L}$ of TE buffer (TRIS: 1M - pH8, EDTA: 0.5M pH8) and $200 \mu \mathrm{L}$ of lysis solution (TRIS: $1 \mathrm{M}$ - pH8, EDTA: $0.5 \mathrm{M}-\mathrm{pH} 8$ and sucrose: $0.7 \mathrm{M}$ ). After a thermic shock at $-80^{\circ} \mathrm{C}$ for $15 \mathrm{~min}$ and at $55^{\circ} \mathrm{C}$ for $2 \mathrm{~min}, 50 \mu \mathrm{L} 10 \%$ sodium dodecyl sulfate (SDS) and $10 \mu \mathrm{L}$ of proteinase $\mathrm{K}(20 \mathrm{mg} / \mathrm{mL})$ were added. The sample was incubated at $37^{\circ} \mathrm{C}$ for $1 \mathrm{~h}$ with gentle stirring and placed again in the block heater at $55^{\circ} \mathrm{C}$ for $20 \mathrm{~min}$. After a quick centrifugation step $(13,000 \mathrm{rpm}$ at $4^{\circ} \mathrm{C}$ for $3 \mathrm{~min}$ ), the supernatant was collected, and $50 \mu \mathrm{L}$ of sodium acetate (3M - pH 5.2) plus $1 \mu \mathrm{L}$ of GenEluteTMLPA (Sigma-Aldrich, $25 \mu \mathrm{g} / \mu \mathrm{L}$ ) were added. One volume of isopropanol was then added and the tubes were centrifuged for $10 \mathrm{~min}$ at $12,000 \mathrm{~g}$ and $4^{\circ} \mathrm{C}$. Two rounds of ethanol $(80 \%)$ washing were carried to purify the pellet of DNA. The remaining ethanol was evaporated using the SpeedVac for 20 min. Finally, $30 \mu \mathrm{L}$ of TE were added and tubes were left for $1 \mathrm{~h}$ at $37^{\circ} \mathrm{C}$. DNA concentration was measured using Nano Drop 1000 spectrophotometer. When DNA concentration was superior to $25 \mathrm{ng} / \mu \mathrm{L}$, a dilution was carried. All tubes were stored at $-20^{\circ} \mathrm{C}$ until analysis.

\section{PCR Amplification}

PCR amplification of the 16S rRNA gene were performed using specific primers (Bd529F and Bd1007R for Bdellovibrio, Bac676F and Bac1442R for Bacteriovorax and Per676F and Per1443R for Peredibacter, [18], as well as universal primers targeting bacteria (515F and 909R, [19]). Adopted from Davidov Y, et al. [4] the specific amplification PCR mixture volume was at $25 \mu \mathrm{L}$ and consisted of (final concentration): $1 \mathrm{x}$ buffer, $0.2 \mathrm{mM} \mathrm{dNTP}, 3 \mathrm{mM} \mathrm{MgCl}_{2}, 0.3 \mathrm{mg} / \mathrm{mL}$ bovine serum albumin (BSA) and $0.625 \mathrm{U}$ Biotaq DNA polymerase (Bioline). In a second step, primers (Forward and Reverse) for each BALO genus were added to the different mixtures. Finally, $1 \mu \mathrm{L}$ of template DNA (BALOs extracted DNA) concentrated at $25 \mathrm{ng} / \mu \mathrm{L}$ was added. A negative control was included and the PCR program was as follows: $94^{\circ} \mathrm{C}-5 \mathrm{~min}$, $30 \times\left(94^{\circ} \mathrm{C}-1 \mathrm{~min}, 58^{\circ} \mathrm{C}-1 \mathrm{~min}, 72^{\circ} \mathrm{C}-3 \mathrm{~min}\right)$, [4] and with a final extension step at $72^{\circ} \mathrm{C}$ for $5 \mathrm{~min}$. For the universal amplification, the mixture volume was at $25 \mu \mathrm{L}$ and consisted of (final concentration): $1 \mathrm{x}$ buffer, $0.4 \mathrm{mM}$ dNTP, $2 \mathrm{mM} \mathrm{MgCl}$, $0.4 \mathrm{mg} / \mathrm{mL}$ bovine serum albumin (BSA), $0.2 \mu \mathrm{M}$ of forward primer $515 \mathrm{~F}, 0.2 \mu \mathrm{M}$ of reverse primer $909 \mathrm{R}$ and $0.5 \mathrm{U}$ Biotaq DNA polymerase (Bioline). Finally, $1 \mu \mathrm{L}$ of template DNA concentrated at $25 \mathrm{ng} / \mu \mathrm{L}$ were added. A negative control was included and the PCR program was as follows: $95^{\circ} \mathrm{C}-2$ min, $30 \times\left(94^{\circ} \mathrm{C}-30 \mathrm{sec}, 58^{\circ} \mathrm{C}-30 \mathrm{sec}, 72^{\circ} \mathrm{C}-30 \mathrm{sec}\right)$, and with a final extension step at $72^{\circ} \mathrm{C}$ for $5 \mathrm{~min}$. Agarose gel analysis was performed for verification of PCR products.

\section{Cloning, Sanger Sequencing and Taxonomic Assignment}

When plaques were detected, both the predator and the prey were extracted, amplified and cloned for sequencing. Prior to cloning, PCR products were purified using GE healthcare illustra GFX kit according to the manufacturer's instructions. The purified products were then measured using a Nano drop 1000 spectrophotometer. Cloning was conducted using TOPO TA Cloning kit (Thermo Fisher Scientific) following manufacturer's recommendation. Briefly, ligation step was carried in $6 \mu \mathrm{L}$ volumes consisting of $1 \mu \mathrm{L}$ of salt solution, $1 \mu \mathrm{L}$ of topo vector and $4 \mu \mathrm{L}$ of purified PCR product. The mix was incubated for $20 \mathrm{~min}$ at ambient temperature. After the incubation time, the mix was put in icy water to stop the ligation process. Next, the transformation process was performed by adding $2 \mu \mathrm{L}$ of the ligation product in $50 \mu \mathrm{L}$ of competent $E$. coli. A thermic shock was executed in icy water for $10 \mathrm{~min}$, immediately thawed into a block heater at $42^{\circ} \mathrm{C}$ for $40 \mathrm{sec}$, and then again in ice for $3 \mathrm{~min}$. After, $250 \mu \mathrm{L}$ of SOC medium were added. The sample was incubated at $37^{\circ} \mathrm{C}$ for $1 \mathrm{~h} 30$ with gentle stirring. Then, 


\section{Open Access Journal of Microbiology \& Biotechnology}

50, 80 and $100 \mu \mathrm{L}$ of $E$. coli were streaked on agar plate. The next day, white clones were selected for DNA amplification. White clones were heated at $95^{\circ} \mathrm{C}$ for $10 \mathrm{~min}$ in order to burst the DNA from E. coli cell. $1 \mu \mathrm{L}$ of DNA was pipetted and added to a PCR mix of $29 \mu \mathrm{L}$ composed of: $1 \mathrm{x}$ buffer, $2 \mathrm{mM}$ dNTP, $2 \mathrm{mM} \mathrm{MgCl}, 0.1 \mu \mathrm{M}$ of forward primer M13F (-20) (5'-GTAAAACGACGGCCAG-3'), $0.1 \mu \mathrm{M}$ of reverse primer M13R (5'-CAGGAAACAGCTATGAC-3') and 0.6 U Biotaq DNA polymerase (Bioline). A negative control was included and the PCR program was as follows: $94^{\circ} \mathrm{C}-10 \mathrm{~min}, 30 \times\left(94^{\circ} \mathrm{C}-60\right.$ sec, $55^{\circ} \mathrm{C}-60 \mathrm{sec}, 72^{\circ} \mathrm{C}-60 \mathrm{sec}$ ), and with a final extension step at $72^{\circ} \mathrm{C}$ for $10 \mathrm{~min}$. Agarose gel analysis was performed for PCR products verification. With these PCR products, 2 plates of 96 wells were prepared and sent to GATC / Euro fins Genomics for single end Sanger sequencing. 10 clones for each prey and 16 clones for each predator with universal and specific primer were sent. Taxonomic assignment of sequences obtained from Sanger sequencing was performed online with NCBI Blastn [20].

\section{Phylogeny}

On one hand, 8 Bdellovibrio reference sequences (including type species) of the 16S rRNA gene were downloaded from NCBI [21], supp. Table 2) and Vampirovibrio chlorellavorus was used here as an out group. On the other hand, 30 assigned sequences of Bdellovibrio (Cloningsequencing) were used to construct the phylogenetic tree. To begin, all sequences were aligned visually using the program MEGA7 [22] via MUSCLE alignment [23]. The alignment was trimmed at both ends in order for all the sequences to fully overlap with each other (255 positions with gaps). The generated file was then formatted to Phylip and Nexus to be respectively used in PhyML 3.12010 [24] and MrBayes 3.2.7a [25]. Model Generator v.85 [26] was used to select the best nucleotide substitution model under corrected Akaike information criterion (AICc) [27] with Number of discrete gamma categories" set to 4 . The program returned TIM + $\mathrm{G}$ as the best substitution model. The tree was built under Maximum likelihood (ML) method using the PhyML 3.1 program with Tree topology search operation" set to SPR and with 100 bootstraps. Then the Bayesian tree was constructed using MrBayes 3.2.7a [24] program with 500,000 generations and a burn-in value of $25 \%$. In the final ML tree, Posterior" probability (PP) and Bootstraps" (BS) values (PP/BS) were added respectively at each node when possible.

\section{Data Accession Numbers}

The Bdellovibrio sequences are available in the Gen Bank database with the following accession numbers: MN556920 to MN556941.

\section{Predatory Spectrum Experiment}

For each possible predator, a predatory spectrum (hostrange) experiment was carried by presenting one prey at a time for the predator in the double-layered agar plate. Two replicates were set for each experiment. The Bdellovibrio exovorus JSS strain was also tested with a variety of preys.

\section{Results}

\section{Characterization of the Preys and Predators}

All colonies isolated from the ALBD sample and selected for the isolation were Gram-negative bacteria. For the TCC samples, 4 colonies were identified as Gram-negative and one colony was Gram-positive (Table 1).

Table 1: Gram Coloration of Isolated Prey Colonies from ALBD and TCC Samples.

\begin{tabular}{|l|l|l|l|}
\hline \multicolumn{2}{|c|}{ ALBD colonies } & \multicolumn{2}{c|}{ TCC colonies } \\
\hline A1 & Gram-negative & T1 & Gram-negative \\
\hline A2 & Gram-negative & T2 & Gram-negative \\
\hline A3 & Gram-negative & T3 & Gram-positive \\
\hline A4 & Gram-negative & T4 & Gram-negative \\
\hline A5 & Gram-negative & T5 & Gram-negative \\
\hline
\end{tabular}

Following the isolation procedure to obtain one or several predators, samples for which turbidity was reduced were then sub-sampled and observed using microscopy. For some of them, we could detect fast moving cells, likely to be BALOs, so that a more in-depth analysis was performed. In fine, predators referred to as $\mathrm{T} 1$ and $\mathrm{A} 4$ displayed distinct plaques. After PCR amplification, cloning and sequencing the taxonomic assignation confirmed that they were BALOs, more particularly Bdellovibrio sp. Indeed, following the molecular approach using the specific primers, 13 out of 16 sequences for both A4 and T1 could be associated to Bdellovibrio $s p$. while only 4 for T1 and 0 for A4 when using the bacterial 


\section{Open Access Journal of Microbiology \& Biotechnology}

universal primer. The phylogenetic analysis revealed that A4 and $\mathrm{T} 1$ was in fact the same microorganism (Figure 1).

On the other hand, all clones associated to the preys and also referred to as A4 and T1 were Pseudomonas sp. Preys referred to as A5 and A3 were assigned to Acinetobacter $s p$. and Pseudomonas sp, respectively, while A5 and A3 predators could not be isolated and identified despite the observation of discrete plaques.

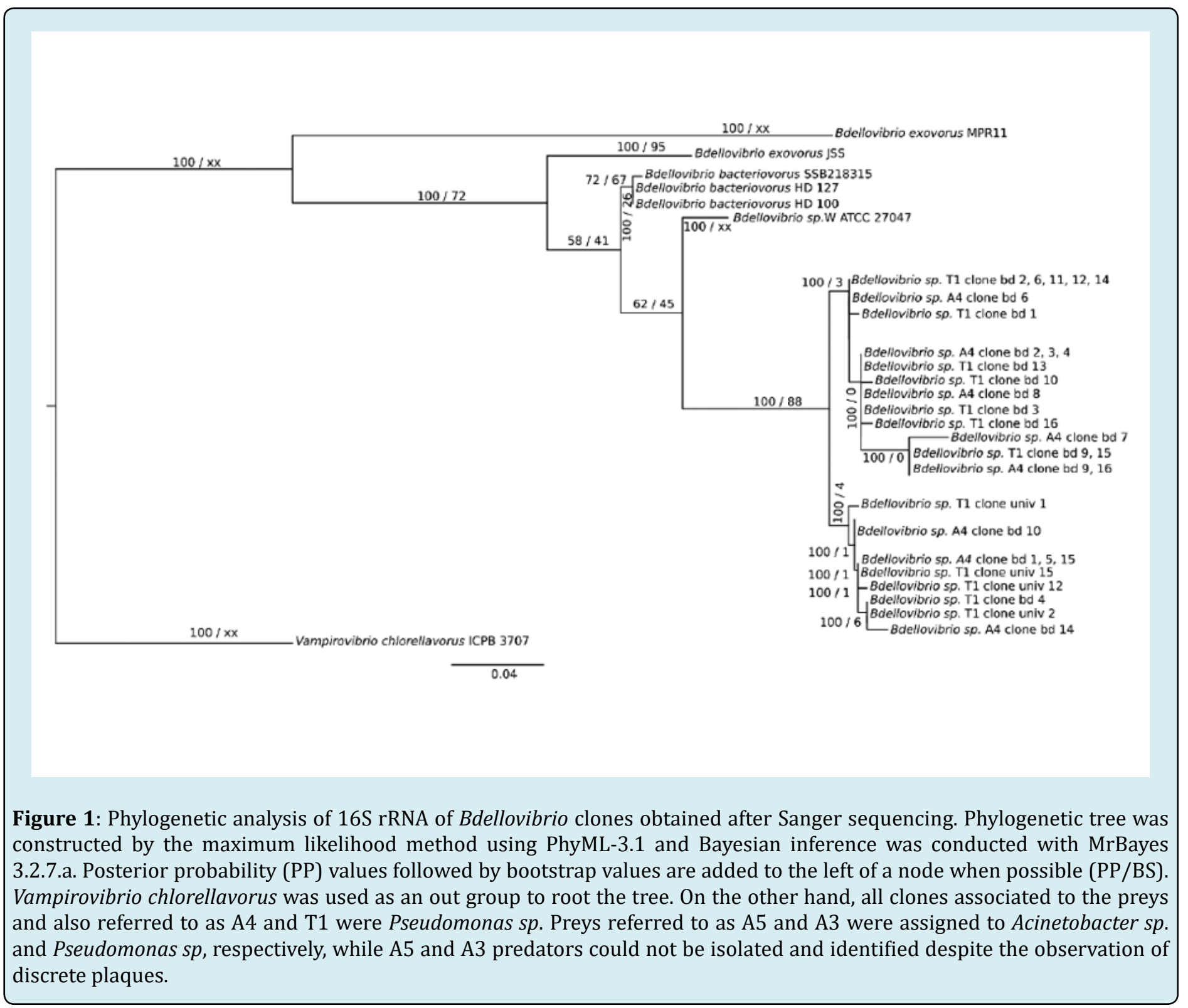

\section{Predation Spectrum (Host-Range Experiment)}

The experiment was carried with Bdellovibrio $s p$. T1, A4 and B. exovorus. Typical plaques were observed with T1 (Pseudomonas sp.), A4 (P. sp.; Figure 2), P. fluorescens and A3 (P. sp.). However, no plaques were detected when using the T4, C. freundii, E. coli, H. alvei, T3 and A5 (Table 2) and other preys. In addition, plaques were observed for all the Bdellovibrio tested with A. salmonicida salmonicida (Supplementary Tables $1 \&$ 2; Supplementary Figure 1). 


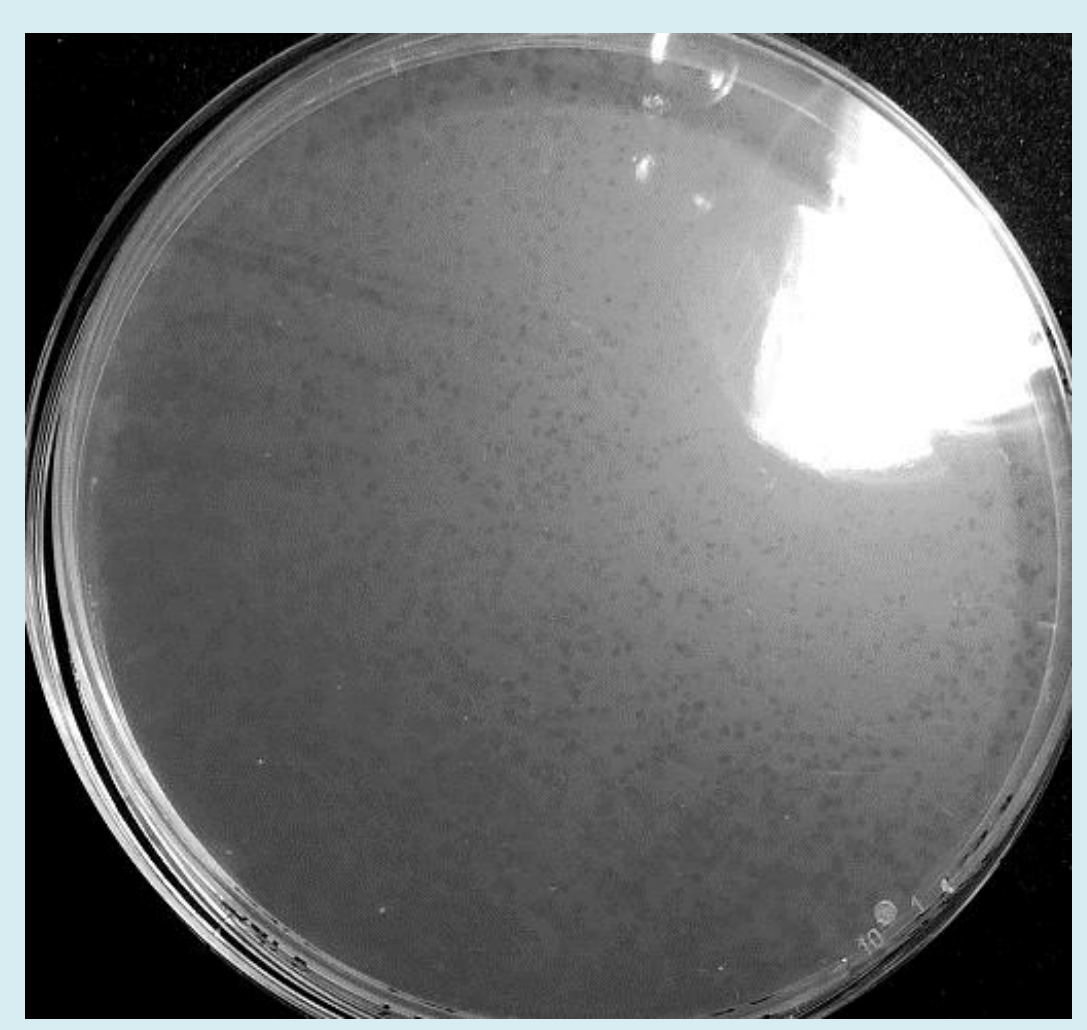

Figure 2: Predation Experiment between Bdellovibrio Sp. T1 and A4 Prey (Pseudomonas sp.) showing distinct small plaque typical of a predation process.

Table 2: Predation experiment with Bdellovibrio sp. T1 and B. exovorus.

\begin{tabular}{|c|c|c|}
\hline Predator & Prey & Predation \\
\hline \multirow{11}{*}{ Bdellovibrio sp. T1 } & T1 (Pseudomonas sp.) & +++ \\
\hline & A4 (Pseudomonas sp.) & +++ \\
\hline & Pseudomonas fluorescens & ++ \\
\hline & A3 (Pseudomonas sp.) & + \\
\hline & T4 (Gram-negative) & - \\
\hline & Aeromonas salmonicida salmonicida SA28 & + \\
\hline & Citrobacter freundii & - \\
\hline & Escherichia coli & - \\
\hline & Hafnia alvei & - \\
\hline & T3 (Gram-positive) & - \\
\hline & A5 (Acinetobacter sp.) & - \\
\hline Bdellovibrio exovorus & Aeromonas salmonicida salmonicida SA28 & + \\
\hline
\end{tabular}

$(-)$ No predation. $(+++)$ multiple and distinct predation plaques. $(++)$ moderate and distinct predation plaques. $(+)$ few predation plaques 


\section{Open Access Journal of Microbiology \& Biotechnology}

Supplementary Table 1: List of cultured phytoplankton from which prey bacteria were isolated

\begin{tabular}{|c|c|c|c|c|}
\hline Class & Family & Genus Species & Source & ID in TCC \\
\hline Chlorophyceae & Ulotrichaceae & Ulothrix sp. & Lake Geneva & TCC1a \\
\hline Cyanophyceae & Phormidiaceae & Planktothrix rubescens & Lake Geneva & TCC13 \\
\hline Cyanophyceae & Synechococcaceae & Synechococcus rhodobaktron & Lake Geneva & TCC33 \\
\hline Zygophyceae & Desmidiaceae & Staurastrum sebaldii & Lake Geneva & TCC106 \\
\hline Chlorophyceae & Oocystaceae & Mychonastes homosphaera & Lake Geneva & TCC108b \\
\hline Chlorophyceae & Scenedesmaceae & Scenedesmus serratus & Lake Geneva & TCC110 \\
\hline Chlorophyceae & Chlamydomonadaceae & Chlamydomonas intermedia & Lake Geneva & TCC113 \\
\hline Chlorophyceae & Scenedesmaceae & Scenedesmus acutus & Lake Geneva & TCC116 \\
\hline Chlorophyceae & Hydrodictyaceae & Pediastrum duplex & Lake Geneva & TCC120 \\
\hline Chlorophyceae & Dictyosphaerioideae & Botryococcus protuberans & Lake Geneva & TCC123 \\
\hline Chlorophyceae & Volvocaceae & Eudorina elegans & Lake Geneva & TCC125 \\
\hline Chlorophyceae & Coelastraceae & Coelastrum reticulatum & Lake Geneva & TCC129 \\
\hline Chlorophyceae & Oocystaceae & Mychonastes sp. & Lake Geneva & TCC136-1 \\
\hline Diatomophyceae & Bacillariaceae & Nitzschia palea & Lake Geneva & TCC139-3 \\
\hline Chlorophyceae & Prasiolaceae & Stichococcus bacillaris & Lake Geneva & TCC145-7 \\
\hline Chlorophyceae & Chlorellaceae & Chlorella vulgaris & Lake Geneva & TCC213 \\
\hline Chlorophyceae & Chlorellaceae & Monoraphidium contortum & Lake Geneva & TCC223 \\
\hline Diatomophyceae & Fragilariaceae & Fragilaria crotonensis & Lake Geneva & TCC365 \\
\hline Diatomophyceae & Fragilariaceae & Fragilaria perminuta & Lake Geneva & TCC743 \\
\hline Chlorophyceae & Scenedesmaceae & Scenedesmus costatus & Lake Geneva & TCC744 \\
\hline Diatomophyceae & Achnanthidiaceae & Achnanthidium minutissimum & Lake Geneva & TCC746 \\
\hline Diatomophyceae & Fragilariaceae & Fragilaria perminuta & Lake Geneva & TCC747 \\
\hline Diatomophyceae & Achnanthidiaceae & Achnanthidium minutissimum & Lake Geneva & TCC748 \\
\hline Diatomophyceae & Fragilariaceae & Fragilaria perminuta & Lake Geneva & TCC749 \\
\hline Diatomophyceae & Achnanthidiaceae & Achnanthidium straubianum & Lake Geneva & TCC833 \\
\hline
\end{tabular}

Supplementary Table 2: Accession numbers of the sequence downloaded from NCBI to construct the phylogenetic tree.

\begin{tabular}{|c|c|}
\hline Sequence name & Accession number \\
\hline Bdellovibrio bacteriovorus strain HD 127 & AJ292760.1 \\
\hline Bdellovibrio sp. W strain ATCC 27047 & AJ292518.1 \\
\hline Bdellovibrio bacteriovorus strain 109J & M61234.1 \\
\hline Bdellovibrio bacteriovorus strain HD100 & NR_027553.1 \\
\hline Bdellovibrio bacteriovorus strain SSB218315 & KT807464.1 \\
\hline Bdellovibrio exovorus strain JSS & EF687743.1 \\
\hline Bdellovibrio exovorus strain MPR11 & MH230062.1 \\
\hline Bdellovibrio exovorus strain KL8 & NR_115142.1 \\
\hline Vampirovibrio chlorellavorus strain ICPB 3707 & NR_104911.1 \\
\hline
\end{tabular}




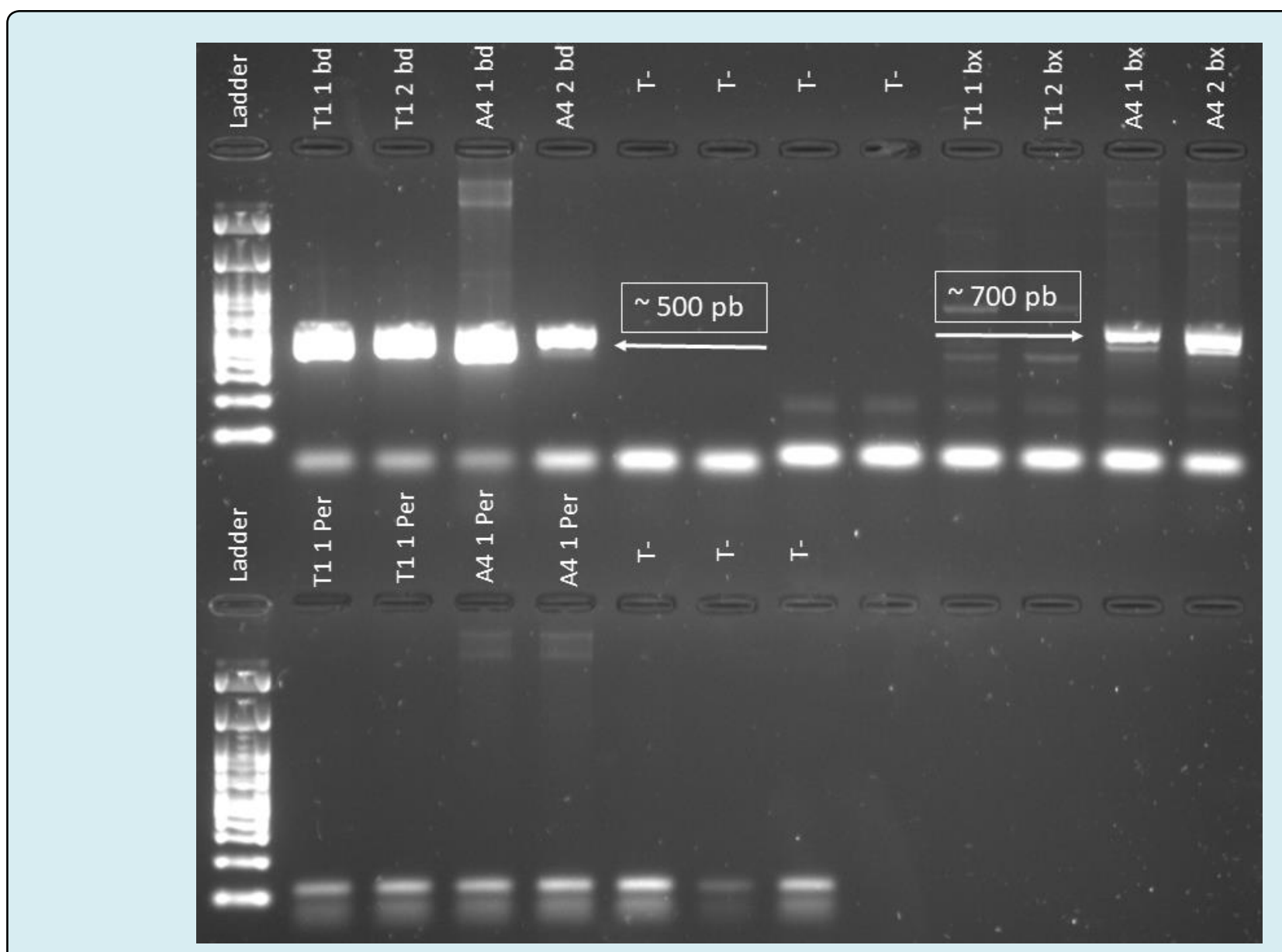

Supplementary Figure 1: Gel photo showing amplification at $\sim 500 \mathrm{pb}$ when using the specific primer of Bdellovibrionaceae on T1 and A4 predators DNA extract. In addition amplification was observed at $\sim 700 \mathrm{pb}$ when using Bacteriovoracaceae specific primer on A4 predator DNA extract. However, no amplification is detected when using Peredibacter specific primer on T1 and A4 predators DNA extract.

\section{Discussion}

BALOs have been mainly studied and isolated in marine and terrestrial environments [4,28,29]. Hence, knowledge gapsfor fresh watersareimportant, especially for (peri-alpine) lakes. In a previous work, we found that Peredibacteracaceae seem to be the most abundant BALO family in Lakes Geneva, Annecy and Bourget and these bacteria were mostly localized in surface [17]. In another study, we revealed that Bdellovibrionaceae reads were the highest in Lake Geneva by Ezzedine JA, et al.[45]. The different results clearly suggested that BALOs can be numerically and functionally important in Lake Geneva. Thus, isolating, characterizing and maintaining one or several BALOs in culture may help to determine their importance in this lake and beyond.

We were moderately successful since we only obtained one Bdellovibrio sp. representative despite an important effort to try to obtain several bacterial predators. We obtained it from a mixture of water sediment and biofilms from the shore. Thus, we do not know if we selected a benthic or a pelagic species, a free-living population or an attached group. It is noteworthy, however, that it has been reported that BALOs can be more present in surface biofilms and sediments than in the water column [30,31]. We also chose a location with natural clean water and far from any wastewater treatment pipes, and this may have reduced our success to isolate different populations. Indeed, some authors reported that BALOs are more concentrated in the waters at the outlet of wastewater treatment plants [32]. However, polluted waters have also been reported by Markelova NY $[33,34]$ to drive BALOs into entering a bdelloplast state in order to survive. At last, while we tried to be not too limiting in terms of prey range, our selection remained relatively low (with only 10 different species or strains) and this may also have contributed to a low isolation success. 


\section{Open Access Journal of Microbiology \& Biotechnology}

We obtained however very interesting results. Firstly, the only predators we could isolate were Bdellovibrio. The reason behind this result, specifically why this genus and not another BALO is difficult to explain since we used only one sample, from one location, and one date. On one hand, maybe the coastal environment of Lake Geneva at this period of time is richer with Bdellovibrio than in other BALOs. In another hand, Bdellovibrio spp could be the easiest BALOs to isolate since they dominate existing isolates. As optimal temperature for growing Peredibacter is between 20 and $30^{\circ} \mathrm{C}$ [8], Bacteriovorax between 15 and $35^{\circ} \mathrm{C}$ [35], and Bdellovibrio between 28 and $30^{\circ} \mathrm{C}[4,15,36]$, our temperature incubation about $25^{\circ} \mathrm{C}$ was unlikely to explain our result. The isolated Bdellovibrio sp. was characterized by small, numerous and distinct predation plaques, smaller but globally similar to those of Bdellovibrio cells growing on Pseudomonas corrugata [37]. In another hand, plaques were different in size and shape from Bdellovibrio growing on $E$. coli. Isolated [15] from Nigerian freshwater bodies. Such results are not surprising since [37] stated that both the shape and size of predation plaques depend on the nature of the predator which produces them. Since these predators belong to different environments, each one may have a different predation strategy or simply behave differently in different laboratory conditions.

Secondly, we found that the predator had a narrow host range with a clear preference for Pseudomonas spp. Indeed, the isolated Bdellovibrio seemed to be a specialist since predation plaques were mainly observed with Pseudomonas, i.e. P. fluorescens ATCC 13525, T1, A4 and A3 preys that were also Pseudomonas $s p$. species. This predation activity against Pseudomonas $s p$ is interesting when one knows that different species or strains of this genus can carry enteric diseases for humans. Unlike Iebba V, et al. [10] and Pantanella F [38] who reported that B. bacteriovorus may predate on Gram-positive bacteria (in case of nutrient deficiency), such a situation was not observed here. In any case, further experiment should be carried to evaluate the impact of BALOs predation on a largest variety of prey. Bdellovibrio could also predate on $A$. salmonicida salmonicida (here a strain recently isolated in our lab from Arctic charr). Bdellovibrio exovorus, which is an epibiotic predator with no bdelloplast formation, was shown to grow on a few variety of preys including Caulobacter crescentus, Acinetobacter johnsonii RS3-17, A. junii RS341, Delftia acidovorans RS3-16, and Aeromonas hydrophila AS12a $[39,40]$. The appearance of predation plaques on A. salmonicida salmonicida SA28 reminds thus the result obtained with $A$. hydrophila. Such a result is promising since bacterial predators of bacteria could be used as bio agents controlling specifically some toxigenic bacterial strains, among which the ones that are multi-resistant to antibiotics, for instance in fish farming $[11,41,42]$ reported that $B$. bacteriovorus $\mathrm{H} 16$ and Halobacteriovorax HBXCO1 predated
Vibrio species that infect and kill shrimps (Penaeus vannamei) and bivalves. In addition [43] showed a correlation between the health status of domestic animals and the abundance of BALOs. The more BALOs are present, the less these animals were exposed to pathogens. Here, a new potential application is highlighted here for salmonids infected by Furunculosis that can cause a significant mortality in a variety of species, including salmons, and in the peri-alpine lakes the Arctic charr [44].

\section{Conclusion}

The isolation and characterization of a new obligate bacterial predator of bacteria highlights the necessity to interest to this functional group of bacteria and probably to other (non-obligate) predators to better understand the functioning of microbial ecosystems. As also proposed in a parallel study for Lake Geneva, we believe that BALOs constitute an important group of bacteria likely to play key roles in the structure, dynamics and diversity of the heterotrophic bacterial community, constituting thus an unseen elephant in the room [45]. In the future, new attempts of isolation will be required as well as the conduction of experiments to precisely define mortality rates induced by such predators.

\section{References}

1. Azam FT, Fenchel JG Field, JS Gray, Meyer-Reil LA, Thingstad F (1983) The Ecological Role of Water-Column Microbes in the Sea. Marine Ecology Progress Series 10: 257-263.

2. Handelsman J (2004) Metagenomics: Application of Genomics to Uncultured Microorganisms. Microbiol Mol Biol Rev 68 (4): 669-685.

3. Jørgensen TS, Xu Z, Hansen MA, Sørensen SJ, Hansen LH (2014) Hundreds of Circular Novel Plasmids and DNA Elements Identified in a Rat Cecum Metamobilome. PLoS One 9(2): e87924.

4. Davidov Y, Friedjung A, Jurkevitch E (2006) Structure Analysis of a Soil Community of Predatory Bacteria Using Culture-Dependent and Culture-Independent Methods Reveals a Hitherto Undetected Diversity of Bdellovibrioand-like Organisms. Environ Microbiol 8 (9): 1667-1673.

5. Hahn MW, Schmidt J, Koll U, Rohde M, Verbarg S et al. (2017) Silvanigrella Aquatica gen. Nov., Sp. Nov., Isolated from A freshwater lake, Description of Silvanigrellaceae Fam. Nov. And Silvanigrellales Ord. Nov., Reclassification of the Order Bdellovibrionales in the Class Oligoflexia, Reclassification of the Famil. Int J Syst Evoly Microbiol 67(8): 2555-2568. 


\section{Open Access Journal of Microbiology \& Biotechnology}

6. Crossman LC, Chen H, Cerdeño-Tárraga AM, Brooks K, Quail MA, et al. (2013) A Small Predatory Core Genome in the Divergent Marine Bacteriovorax Marinus SJ and the Terrestrial Bdellovibrio Bacteriovorus. ISME J 7(1): 148-160.

7. Chen H, Athar R, Zheng G, Williams HN (2011) Prey Bacteria Shape the Community Structure of Their Predators. ISME J 5(8): 1314-1322.

8. Davidov Y, Jurkevitch E (2004) Diversity and Evolution of Bdellovibrio-and-like Organisms (BALOs), Reclassification of Bacteriovorax Starrii as Peredibacter Starrii Gen. Nov., Comb. Nov., and Description of the Bacteriovorax-Peredibacter Clade as Bacteriovoracaceae Fam. Nov. Int J Syst Evol Microbiol 54 (5): 1439-1452.

9. Williams HN, Lymperopoulou DS, Athar R, Chauhan A, Dickerson TL, et al. 2016. Halobacteriovorax, an Underestimated Predator on Bacteria: Potential Impact Relative to Viruses on Bacterial Mortality. ISME J 10(2): 491-499.

10. Iebba V, Totino V, Santangelo F, Gagliardi A, Ciotoli L, et al. 2014. Bdellovibrio Bacteriovorus Directly Attacks Pseudomonas Aeruginosa and Staphylococcus Aureus Cystic Fibrosis Isolates. Front Microbiol 5: 280.

11. Cao H, An J, Zheng W, He S (2015) Vibrio Cholerae Pathogen from the Freshwater-Cultured Whiteleg Shrimp Penaeus Vannamei and Control with Bdellovibrio Bacteriovorus. J Invertebr Pathol 130: 13-20.

12. Chen H, Williams HN (2012) Sharing of Prey: Coinfection of a Bacterium by a Virus and a Prokaryotic Predator. mBio 3(2): e00051-12.

13. Kandel PP, Pasternak Z, Van Rijn J, Nahum O, Jurkevitch E (2014) Abundance, Diversity and Seasonal Dynamics of Predatory Bacteria in Aquaculture Zero Discharge Systems. FEMS Microbiol Ecol 89(1): 149-161.

14. Li N, Williams HN (2015) 454 Pyrosequencing Reveals Diversity of Bdellovibrio and like Organisms in Fresh and Salt Water. Antonie van Leeuwenhoek 107(1): 305-311.

15. Sar TT, Umeh E, Akosu DD (2015) Occurrence, Detection and Isolation of Bdellovibrio Spps. from Some Fresh Water Bodies in Benue State, Nigeria. Microbiology Journal 5(1): 21-27.

16. Van Essche M, Sliepen I, Loozen G, Van Eldere J, Quirynen M, et al. (2009) Development and Performance of a Quantitative PCR for the Enumeration of Bdellovibrionaceae. Environ Microbiol Rep 1(4): 228233.
17. Benoit Paix, Ezzedine JA, Jacquet S (2019) Diversity, Dynamics and Distribution of Bdellovibrio and like Organisms in Perialpine Lakes. AEM pp: 02494-02518.

18. Jurkevitch E (2006) Isolation and Classification of Bdellovibrio and Like Organisms. Curr Protoc Microbiol.

19. Wang F, Men X, Zhang G, Liang K, Xin Y, et al. (2018) Assessment of 16S RRNA Gene Primers for Studying Bacterial Community Structure and Function of Aging Flue-Cured Tobaccos. AMB Express 8(1): 182.

20. Altschup SF, Gish W, Miller W, Myers EW, Lipman DJ (1990) Basic Local Alignment Search Tool. J Mol Biol 215(3): 403-10.

21. Benson DA, Cavanaugh M, Sayers EW (2013) GenBank. Nucleic Acids Res 41: 36-42.

22. Kumar S, Stecher G, Tamura K (2016) MEGA7: Molecular Evolutionary Genetics Analysis Version 7.0 for Bigger Datasets. Mol Biol Evol 33(7): 1870-1874.

23. Edgar RC (2004) MUSCLE: Multiple Sequence Alignment with High Accuracy and High Throughput. Nucleic Acids Res 32 (5): 1792-1797.

24. Guindon S, Dufayard JF, Lefort V, Anisimova M, Hordijk W et al. (2010) New Algorithms and Methods to Estimate Maximum-Likelihood Phylogenies: Assessing the Performance of PhyML 3.0. Syst Biol 59(3): 307-321.

25. Ronquist F, Teslenko M, Mark PVD, Ayres DL, Darling A, et al. (2012). MrBayes 3.2 : Efficient Bayesian Phylogenetic Inference and Model Choice across a Large Model Space. Syst Biol 61(3): 539-542.

26. Keane TM, Creevey CJ, Pentony MM, Naughton TJ, McInerney JO (2006) Assessment of Methods for Amino Acid Matrix Selection and Their Use on Empirical Data Shows That Ad Hoc Assumptions for Choice of Matrix Are Not Justified. BMC Evol Biol 6: 29.

27. Akaike H (1973) Information Theory and an Extension of the Maximum Likelihood Principle. In: Petrov BN \& Csaki F (Eds.), Proceedings of the $2^{\text {nd }}$ International Symposium on Information Theory Budapest: Akademiai Kiado, pp: 267-281.

28. Williams $\mathrm{NH}, \mathrm{Nan} \mathrm{Li}$, and Expedition 349 Scientists (2018) Data Report: Exploring the Presence of Bdellovibrio and like Organisms in Deep-Sea Sediment by Culture-Independent and Culture-Dependent Methods. International Ocean Discovery Program publications 349: 4-7.

29. Sutton DC, Besant PJ (1994) Ecology and Characteristics 


\section{Open Access Journal of Microbiology \& Biotechnology}

of Bdellovibrios from Three tropical Marine Habitats. Marine Biology 119(2): 313-320.

30. Williams HN, Schoeffield AJ, Guether D, Kelley J, Shah D, et al. (1995) Recovery of Bdellovibrios from Submerged Surfaces and Other Aquatic Habitats. Microbial Ecology 29: 39-48.

31. Williams HN, Piñeiro S (2006) Ecology of the Predatory Bdellovibrio and like Organisms. Microbiology Monographs 4: 213-248.

32. Aguirre M, Abad D, Albaina A, Cralle L, Goñi-Urriza MS, et al. (2017) Unraveling the Environmental and Anthropogenic Drivers of Bacterial Community Changes in the Estuary of Bilbao and Its Tributaries. PLoS One 12(6): e0178755.

33. Markelova NY (2002) Effect of Toxic Pollutants on Bdellovibrio. Process Biochemistry 37(10): 1177-1181.

34. Markelova NY, Gariev IA (2005) Predatory Bacteria Bdellovibrio: Survival Strategy. Process Biochemistry 40(3-4): 1089-1094.

35. Baer ML, Ravel J, Chun J, Hill RT, Williams HN (2000) A Proposal for the Reclassification of Bdellovibrio Stolpii and Bdellovibrio Starrii into a New Genus, Bacteriovorax Gen. Nov. as Bacteriovorax Stolpii Comb. Nov. and Bacteriovorax Starrii Comb. Nov., Respectively. Int J Syst Evol Microbiol 50(1): 219-224.

36. Fratamico, PM, Whiting RC (1995) Ability of Bdellovibrio Bacteriovorus 109j to Lyse Gram-Negative Food-Borne Pathogenic and Spoilage Bacteria. J Food Prot 58 (2): 160-164.

37. Jurkevitch E, Davidov Y (2006) Phylogenetic Diversity and Evolution of Predatory Prokaryotes. Microbiology Monographs 4: 11-56.

38. Pantanella F, Iebba V, Mura F, Dini L, Totino V, et al. (2018)
Behaviour of Bdellovibrio Bacteriovorus in the Presence of Gram-Positive Staphylococcus Aureus. New Microbiol 41(2): 145-152.

39. Koval, SF, Hynes SH, Flannagan RS, Pasternak Z, Davidov Y, et al. (2013) Bdellovibrio Exovorus Sp. Nov., a Novel Predator of Caulobacter Crescentus. Int J Syst Evol Microbiol 63(1): 146-151.

40. Chanyi RM, Ward C, Pechey A, Koval SF (2013) To Invade or Not to Invade: Two Approaches to a Prokaryotic Predatory Life Cycle. Can J Microbiol 59(4): 273-279.

41. Richards GP, Johnna PF, Keyana DA, Parent MA, Soroka DS, et al. (2012) Predatory Bacteria as Natural Modulators of Vibrio Parahaemolyticus and Vibrio Vulnificus in Seawater and Oysters. Applied and Environmental Microbiology 78(20): 7455-7466.

42. Ottaviani D, Chierichetti S, Angelico G, Forte C, Rocchegiani E, et al. (2018) Halobacteriovorax Isolated from Marine Water of the Adriatic Sea, Italy, as an Effective Predator of Vibrio Parahaemolyticus, Non-01/ 0139 V. Cholerae, V. Vulnificus. J Appl Microbiol 125(4): 1199-1207.

43. Schwudke D, Strauch E, Krueger M, Appel B (2001) Taxonomic Studies of Predatory Bdellovibrios Based on 16S RRNA Analysis, Ribotyping and the Hit Locus and Characterization of Isolates from the Gut of Animals. Syst Appl Microbiol 24(3): 385-394.

44. Braden LM, Shona KW, Alyson BJ, Brown, Iderstine CV, et al. (2019) Vaccine-Induced Protection against Furunculosis Involves Pre-Emptive Priming of Humoral Immunity in Arctic Charr. Front Immunol 10: 120.

45. Ezzedine JA, Jacas L, Desdevises Y, Jacquet S (2020) Bdellovibrio and like organisms in Lake Geneva: An unseen elephant in the room? Front Microbiol ID: 507411.

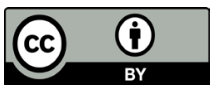

